\title{
Technology "smart grid" at production facilities of the energy complex
}

\author{
Mikhail Koshkin \\ 2nd year master's student of the department «Entrepreneurship and foreign economic activity» \\ Bauman University, Moscow
}

\begin{abstract}
This paper describes the technology of "smart grids", its specific application in the energy sector, the positive aspects of the technology and its impact on the production and transmission of electricity.

Keywords: smart grids, production, energy.
\end{abstract}

\section{Introduction}

In recent years, Russia has hosted many conferences on the topic of "smart grids" at production facilities of the energy complex: among them World Summit Smart Energy Russia, Intelligent Energy Systems, RECONSTRUCTION OF ENERGY, Russian Energy: a new investment cycle, Energy of the 21st century: sustainable development and intellectual Management, ENERGY AND ENERGY SAVING: THEORY AND PRACTICE.

At the World Smart Energy Summit Russia, which brought together 500 experts from 25 countries (March 2019), both industry leaders and representatives of startups - Schneider Electric, Digital Transformation Factory, NORBIT, EnergoTechService, participated Voltaware, Wirenboard, Prosoft Systems, Tibbo Systems, Energomery, Petersburg Metering Plant, as well as ITSumma, RCNTEC, Erachain, MCA, Smart Energy, InfoPro.

Why did small businesses appear and feel good in the energy sector? According to Mikhail Andronov, president of Rusenergosbyt, so far in society "there is a myth that energy is only for large corporations, mostly state-owned, and that it is impossible to participate in small business," he explained. - Today we see a big redistribution in the energy sector - a new niche is emerging (this is the production of drives, solar panels, wind turbines, as well as the emergence of businesses for their sale, installation, and maintenance), which will be filled with young and energetic businessmen" [1].

\section{Methods}

At these conferences and in scientific discussions [2], various issues are discussed. Using the narrative method, we will try to unravel the tangle of contradictions in the topic under study. First, we note that today in the central part of Russia, energy is becoming digital; moreover, "smart grids" have begun to be actively introduced, which make it possible to combat illegal interconnections, unaccounted-for electricity consumption, help reduce free capacity, optimize the operation of power plants and increase the flexibility of energy sources. But in the regions, nevertheless, non-accounting electricity consumption is still 
flourishing, there are huge reserves of free capacity for which enterprises pay and do not use them, there is no flexibility of energy sources.

This problem arose due to the vast transformation, scalability of the grid across Russia, the complexity and opacity of the economy. Industrial energy is faced with the task of not only saving energy but also its reliable and uninterrupted transmission. Equipment (power plants, transport systems) in the regions has a high depreciation of $56 \%$, and the equipment itself - the figure reaches up to $80 \%$, makes this a global problem for the whole country. In addition, inefficient use of power can lead to fatal problems, and this arose due to the increased load at times over the past decades, although the power supply structure remained unchanged [2-3].

Smart grids are modernized power supply channels operating using switching and information technologies [8]. The technology of "smart grids" allows you to cover all aspects of the electric power industry such as generation, transmission, distribution, which allows for production control. An information system is being created in which information on the state of production and the energy system as a whole is stored. The information obtained using sensors is used to improve production, research, planning, quality, enterprise economics, and information system.

Implementation of the "smart grids" technology allows you to:

- increase the throughput capacity of overhead power lines up to $30 \%$, by taking into account regime and climatic factors [5];

- $\quad$ increase the reliability of power transmission up to $30 \%$;

- reduce electricity losses up to $25 \%$;

- simplifie load schedules due to the use of electric power storage devices of greater power up to $25 \%$;

- cope with unaccounted electricity consumption [6].

We also add that the concept of "smart grids" in the field of electricity metering received state support, which was enshrined in the document "Energy Strategy of Russia for the Period until 2030" [6]. Many companies are actively involved in this work: for example, Rosseti PJSC carried out and is implementing measures to introduce smart grids into its production, in 2016 they managed to save 2.4 billion $\mathrm{kWh}$, that is, reduce losses to $11 \%$ in all household $[5]$.

\section{Conclusion}

With the development of technology, "smart grids" are becoming an integral factor in the industry in the electric power industry. "Smart grids" "include a synergistic effect that affects all aspects of the life of a modern enterprise. However, it is important to conduct studies showing how, due to what factors, energy losses are reduced, how and at which enterprises in the industry labor productivity increases. More importantly, smart grid technologies require a quantitative assessment both from the point of implementation in various regions of the country and from use not only for industrial energy but also, for example, for unmanned vehicles and other devices.

\section{Reference}

1. At the World Smart Energy Summit Russia in Moscow, they discussed the innovative transformation of the energy market//04/01/2019, source: http://www.comnews.ru/content/118810/2019-04-01/na-world-smart-energy-summitrussia-v-moskve-obsudili-innovacionnuyu-transformaciyu-energeticheskogorynka\#ixzz6Bxu7zPFn. 
2. See for example: Porfiryev B.N. "Green" economy: global tends and prospects // Bulletin RAS, 2012. Vol. 82, No. 4. pp. 323-344; Porfiryev B.N., Roginko S.A.. Alternative energy and socially oriented economy // Bulletin of St. Petersburg University. Series 5. Economy. 2016, Issue. 3. pp. 4-19. DOI: 10.21638/11701/spbu05.2016.301; Kamolov S.G., Korneeva A.M. Future Technologies for "smart cities" // Bulletin of Moscow State Regional University. Series: Economy. 2018. No. 2. p. 100-114 DOI: 10.18384/23106646-2018-2-100-114 ; Mozokhin A.E., Shvedenko V.N. Analysis of the development directions of digitalization of domestic and foreign energy systems // Scientific and Technical journal of Information Technologies, Mechanics and Optics. 2019. Vol. 19. No 4. p. 657-672. doi: 10.17586/2226-1494-2019-19-4-657-672

3. Drogovoz P.A., Burovtsev D.M., Reshetnikov A.I. Means of engineering analysis and their role in the product life cycle // Economics and Entrepreneurship. 2016. No. 9. p.724729.

4. Reshetnikov A.I., Sadovsky G.L. The introduction of engineering analysis technologies in the context of digital modernization of industry // Economics and Entrepreneurship. 2017. No. 3. p.707-710.

5. A.M. Staev, mag.; scientific supervisor V.I. Colibaba. Smart grids as a means of reducing losses in the transmission and distribution of electric power // Thirteenth international scientific and technical conference of students, graduate students and young scientists: Materials of the conference. In 6 volumes. 2018. p.40.

6. The energy strategy of Russia for the period until 2030: approved by the government of the Russian Federation 09/13/2009.

7. . Petrova .V., Girshin S.S., Lyashkov A.A., Bigun A.Ya. Analytical decision of the equation of thermal balance of the airline wire in the conditions of forced convection // Modern problems of science and education. 2015. No. 1-1. p. 218.

8. Lyapunov A.I., Gase D.D., Fedoryak L.I. Intelligent electric networks. Smart grid // collection of articles of the International scientific and practical conference: in 3 parts. 2017, p. 77-80. 